\title{
Methods for Biodiversity Assessment: Case Study in an Area of Atlantic Forest in Southern Brazil
}

\author{
Maria Raquel Kanieski, Solon Jonas Longhi and \\ Philipe Ricardo Casemiro Soares \\ Additional information is available at the end of the chapter \\ http://dx.doi.org/10.5772/intechopen.71824
}

\begin{abstract}
Populations and species are disappearing due to disturbances in the environment caused by human activities. Given, the obvious risk of loss of diversity, it is increasingly necessary to take actions concerning preservation, in which safety features are necessary for measuring the variation of diversity in space and time. The aim of this study was to evaluate the structure and diversity in the arboreal component and natural regeneration in an area of Araucaria Forest in Southern Brazil. The vegetation sampling was performed by analyzing 180 subunits of $10 \times 10 \mathrm{~m}$, where all the arboreal individuals and natural regeneration were inventoried. Different alpha and beta indexes of diversity were calculated. The Margalef, Shannon, and the Beta indexes were underestimated, possibly influenced by the size of sample unit. Index Menhinick represented the diversity in a very real form, even in small sampling units. The indexes of Simpson and MacIntosh denote low dominance and the equity indexes showed high uniformity in species.
\end{abstract}

Keywords: Mixed Rainy Forest, alpha indexes, beta indexes, biodiversity evaluation, natural regeneration, arboreal component

\section{Introduction}

Biodiversity is one of the fundamental properties of nature and source of immense potential for economic use. It is the basis of agricultural activities, livestock, forestry, and fishing, and also for the strategic biotechnology industry. The ecological functions performed by biological diversity are still little understood, although we consider it to be responsible by natural processes and products provided by ecosystems and species that sustain other life forms and change the biosphere, making it suitable and safe for life [1]. 
Biological diversity or biodiversity are expressions that refer to the variety of life on the planet, or to the property of living systems to be distinct. It includes plants, animals, microorganisms, ecosystems, and ecological processes in a functional unit [2].

The diversity is regarded as an indication of the ecosystem well-being. It indicates directly the protection of certain place, the higher the value, the larger the biodiversity of the ecosystem in question [3].

Because it is an extremely complex structure, there is a problem to evaluate biodiversity, so we need to find simplified variables for its determination [4]. Some of them-as the composition, type of regeneration, introduced species, the presence of dead trees and the landscapehave been defined according to the 4th Ministerial Conference on the protection of forests, in Vienna, 2002. Especially biodiversity is important, since it represents the state of conservation of ecosystems, including forests, where it can help evaluate the sustainability of the resources are managed [1].

Biological diversity is a central theme of ecological theory and has been the subject of many discussions. Currently, researchers have developed a large number of parameters for the measurement of biodiversity as an indicator of the state of ecological systems, with practical applicability for purposes of conservation, management, and environmental monitoring [5].

Biodiversity can be expressed in four levels: diversity of genes, species, and ecosystems settlement. It can be appreciated by the number (wealth) of different biological categories and relative abundance (evenness) of these categories; and also for variability in local level (alpha diversity), the complementarity between biological habitats (beta diversity) and variability between landscapes (gamma diversity) [6]. It includes, therefore, all the living or biological resources, genetic resources, and their components.

Any environmental protection strategy must ensure the maintenance of biodiversity. All the living beings that inhabit a country constitute an irreplaceable heritage, because each species, as well as each population, has in its genetic composition information from millions of years of evolutionary adaptations. However, in order to exercise management plans and protection of nature reserves, trusted tools able to measure its variation in space and time are required.

Assessing the biodiversity of an ecosystem by its forestry component assumes that the arboreal component is what sustains a forest ecosystem [7]. Already the quantification of diversity through natural regeneration allows a complete characterization of the forest as an ecosystem, and not only by its arboreal component. This approximate evaluation of possible interventions made in settlements, as well as the intensity and provides a rough overview of the volume of the existing biomass in the forest, whose presence can be very relevant with regard to fire prevention, energy potential, and characterization of biodiversity.

Considering the importance of the subject, the objective of this work is to evaluate the arboreal component and natural regeneration biodiversity in an Atlantic Rainy Forest area in Southern Brazil, through different diversity indices in order to find the variables that better represent the current status of diversity in study environment. 


\section{Material and methods}

\subsection{Characterization of the study area}

This study was conducted on National Forest (FLONA) of São Francisco de Paula, administered by the Chico Mendes Institute for Biodiversity Conservation (ICMBio), constituting a conservation unit of sustainable use. The aim of this type of conservation unit (UC) is to make nature conservation with the sustainable multiple uses of its natural resources and stimulate scientific research, with emphasis on methods for sustainable forest management [8].

The FLONA is located in the northeast of the State of Rio Grande do Sul, in southern Brazil, in the city of San Francisco de Paula. It has a total area of 1606.69 ha, which 9019 ha are occupied by native forests (Mixed Rainy Forest and Dense Rainy Forest), over 600 ha by planted forests (Pinus spp., Araucaria angustifolia, and Eucalyptus spp.) and the rest by other areas such as fields, lakes, infrastructure among others.

The region is one of the wetter of the State, with more than $2000 \mathrm{~mm}$ rainfall per year and with annual average temperature of approximately $14.5^{\circ} \mathrm{C}$. According to the Köppen's climate classification, the climate is classified as " $\mathrm{Cfb}$ " mesothermic medium [9]. The average relative humidity is $83.9 \%$. Summer is characterized by mild temperatures and winter by constant and intense cold, where the average temperature is close to $0^{\circ} \mathrm{C}$. Frosts are common in the cooler half and may snow in winters.

The types of soil found in the FLONA are Cambisols, Chernozems, and Newsoils [10]. Geomorphology is marked by a strongly wavy relief in the northern part, with an altitude of $930 \mathrm{~m}$ and rugged in the South, forming canyons with more than $100 \mathrm{~m}$ in depth [11] (Figure 1).

The predominant forest vegetation belongs to the Mixed Rainy Forest. In addition to Araucaria angustifolia (Bertol.) Kuntze, which prints a physiognomic character in this vegetation, it is common to find other tree species such as Sebastiania commersoniana (Baill.) L. b. SM. \& Downs, Cedrela fissilis Vell., Podocarpus lambertii Klotzsch ex Endl., among others. It has the peculiarity to be a transition zone between the Mixed Rainy Forest and Dense Rainy Forest, with endemic species as Oreopanax fulvum Marchal, typical of the Atlantic forest [12]. The author even describes the endemism does not get more accentuated because there is a physical barrier to the species by the existence of the Canyons.

\subsection{Sampling}

The work was performed in six permanent plots of $100 \times 100 \mathrm{~m}\left(10,000 \mathrm{~m}^{2}\right)$, which were divided into 10 tracks of $10 \times 100 \mathrm{~m}\left(1000 \mathrm{~m}^{2}\right)$ and these subdivided into 10 subunits of $10 \times 10 \mathrm{~m}\left(100 \mathrm{~m}^{2}\right)$. Within each plot, 30 subunits were drawn, being three subunits by track from 10 total tracks in each unit of $100 \times 100 \mathrm{~m}$, where vegetation surveys and environmental parameters were made. The distribution of selected subplots in each parcel can be observed in Figure 2 . 


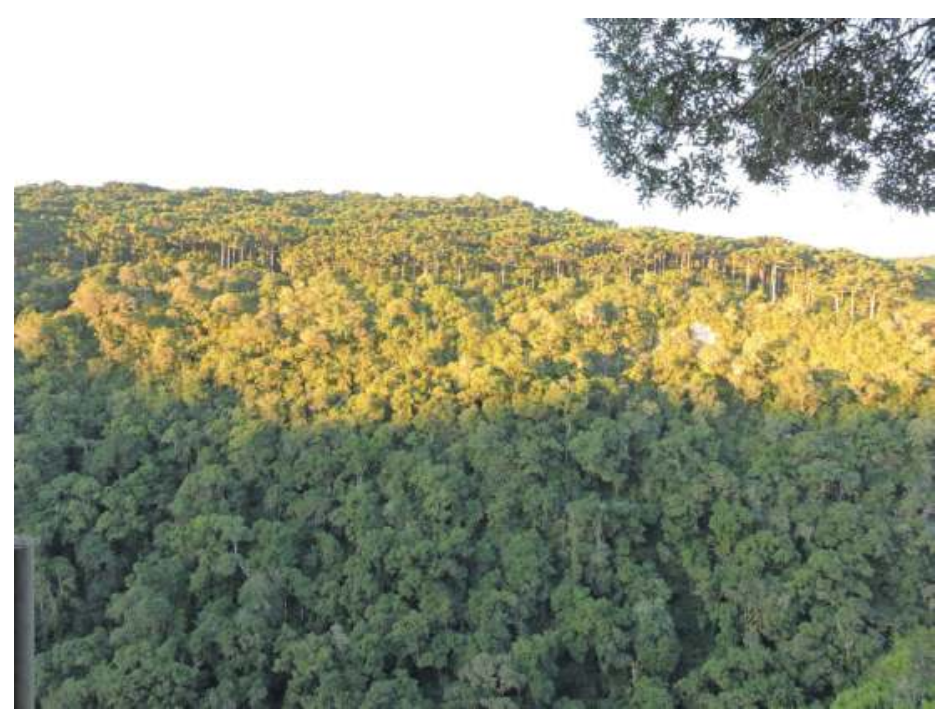

Figure 1. View from the FLONA of São Francisco de Paula, Rio Grande do Sul, Brazil.

\section{Tracks}

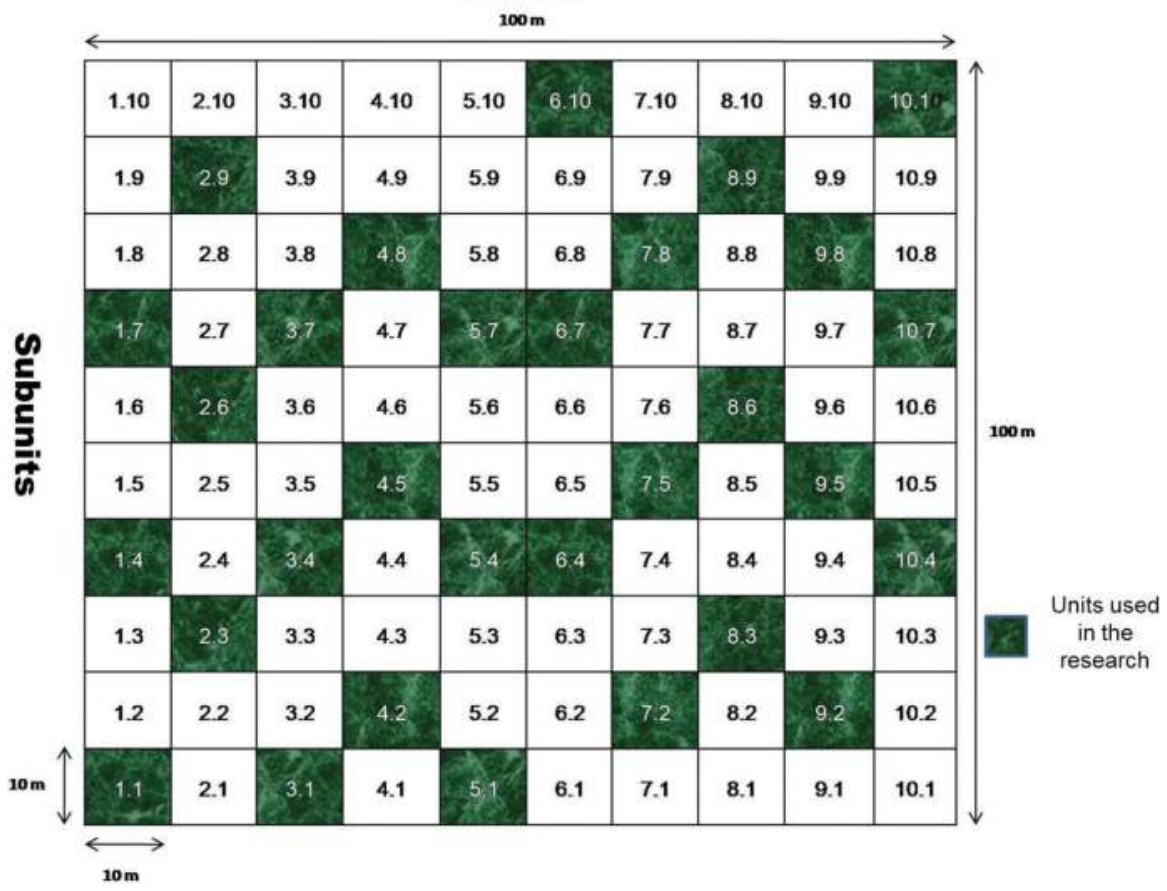

Figure 2. Scheme of subplots in each sampling unit used in this study in southern Brazil. 


\subsection{Data collection}

All individuals over $1.30 \mathrm{~m}$ and with a circumference at breast height $(\mathrm{CBH})$ from $3 \mathrm{~cm}$, minimum, and up to the limit of $29.9 \mathrm{~cm}$ are considered as natural regeneration. As an arboreal component, we considered all individuals with $\mathrm{CBH}$ greater than or equal to $30 \mathrm{~cm}$. Individuals sampled were numbered and identified botanically, collecting botanical material, in case of doubt, registering the number of plants and the common names. The identification in level of family, genus, and species, was carried out consulting the Herbarium of the Department of Forest Sciences at de Santa Maria Federal University, according to the APG II system [13].

\subsection{Biodiversity indices}

Biodiversity indices (Table 1) that provided the evaluation for this work were presented by $[14,15]$. These were calculated for each sampling unit leased in the study area, both for natural regeneration and for the arboreal component.

\subsubsection{Alpha diversity}

The majority of the proposed methods to quantify the biodiversity of species refer to the diversity within communities, namely as alpha diversity. Within this, there are methods based

\begin{tabular}{|c|c|c|}
\hline \multirow[t]{2}{*}{ Species richness } & Margalef index & $R_{1}=\frac{(S-1)}{\ln n}$ \\
\hline & Menhinick index & $R_{2}=\frac{S}{\sqrt{n}}$ \\
\hline \multirow[t]{2}{*}{ Dominance } & Simpson index & $D=\sum p_{i}^{2}$ \\
\hline & MacIntosh index & $D=\frac{n-U}{n-\sqrt{n}}$ \\
\hline Information & Shannon index & $H^{\prime}=-\sum_{i=1}^{s}\left(p_{i}\right)\left(\ln p_{i}\right)$ \\
\hline \multirow[t]{3}{*}{ Equity } & Pielou index & $J^{\prime}=\frac{H^{\prime}}{H_{\max }^{\prime}}$ \\
\hline & Alatalo index & $F=\frac{N 2-1}{N 1-1}$ \\
\hline & Hill index & $E^{\prime}=\frac{N 2}{N 1}$ \\
\hline \multirow[t]{2}{*}{ Similarity } & Jaccard index & $I_{j}=\frac{c}{a+b+c}=\frac{c}{A+B-c}$ \\
\hline & Sorensen index & $I_{s}=\frac{2 c}{a+b}=\frac{2 c}{A+B-c}$ \\
\hline \multicolumn{3}{|c|}{$\begin{array}{l}R_{1}=\text { Margalef index; } R_{2}=\text { Menhinick index; } S=\text { total number of species; } n=\text { total number of individuals; } D=\text { Simpson } \\
\text { index; } p_{i}=\text { proportion of species in a Community }\left(p_{i}=n_{i} / n\right) ; d=\text { MacIntosh index }(i=1,2,3, \ldots, S) ; H^{\prime}=\text { Shannon index } \\
J=\text { Pielou index; } H \text { 'max }=\ln (S)=\text { Alatalo index; } N=\text { number of abundant species }=\mathrm{e}^{\mathrm{H}} ; N 2=\text { number of very abundan } \\
\text { specie }=1 / D ; E=\text { Hill index. } I_{j}=\text { Jaccard index; } I=\text { Sorensen index; } A=\text { number of species present on the site } A ; B=\text { number } \\
\text { of species present on the site } B ; a=\text { number of species unique to the site } A ; b=\text { number of species unique to the site } B ; \text { and } \\
c=\text { number of species present in both places }(A \text { and } B) \text {. }\end{array}$} \\
\hline
\end{tabular}

Table 1. Alpha and Beta diversity indices used in the work evaluation. 
on quantification of the number of species (species richness) and those based on community structure, in the other hands, in proportion of the value of importance of each species. These can still be based on the information, on dominance or equity of the Community [15].

\subsubsection{Species richness}

The measures of species richness provide an understandable and instantaneous expression of diversity [5]. Within the species richness indices, we can cite the Margalef and Menhinick indices (Table 1). These indices do a relationship between the number of species and the number of individuals, and the larger the area of the sampling unit. The greater the number of species entered, the greater the value of the index $[5,15,16]$. One of the great advantages of Margalef and Menhinick index is its ease calculation, being used successfully in several scientific papers [5].

\subsubsection{Information}

The most commonly indices used are those based on information theory. These indices are based on the logic that the diversity, or information, in a natural system, can be measured in a similar way to information contained in a code or message [5]. Shannon and Wiener obtained the function known as Shannon-Wiener index (Table 1). In many works, researches wrongly named it as "Shannon-Weaver" $[17,18]$. This index considers that individuals are sampled at random from a population "indefinitely large" [5, 16, 19].

The Shannon index assumes zero value when there is only one species and the logarithm of the number of species, when the same number of individuals represents all species [5]. Shannon values generally vary between 1.3 and 3.5, and may exceed 4.0, and reach around 4.5 in tropical forest environments [20]. The authors even claim that this index assigns greater value to rare species and is one of the best indices to be used in comparisons, if there is no objective in separating abundance to rarity.

\subsubsection{Dominance}

The indexes based on dominance are inverse parameters to the concepts of uniformity or equity of the community. These indices take into account the representativeness of the species with the highest value of importance, without evaluating the contribution of other species [15]. Among these, we can cite the Simpson and MacIntosh indices (Table 1). The Simpson index shows the probability that two individuals taken at random from a given community are of different species. This index is heavily influenced by the most abundant species of sampling unit while it is least sensitive to species richness $[5,16]$. The Simpson index varies from 0 to 1 , and the closer to 1 the more dominance. On the other hand, the MacIntosh will introduce greater dominance when their values are closer to 0 . The index of MacIntosh is not a dominance index; however, it can be calculated as a measure of diversity or dominance, which is independent of the total number of individuals [5].

\subsubsection{Equity or uniformity}

The equity or uniformity indices show how the number of individuals are distributed among the species, denoting less or greater uniformity in the composition of the parcels. Among these, we can cite the Pielou, Hill, and Alatalo (Table 1). Pielou index is the most commonly 
used within the category equity, and measures the proportion of diversity observed with respect to the maximum expected diversity. The value of this index varies from 0 to 1 , and when it reaches the value 1 , it means that all species are equally abundant $[15,16]$.

The index of Hill is less used for vegetation, with greater use in wildlife studies. This index refers to the distribution of the abundance of the species, or the manner in which the abundance is distributed between the species in a community. When all species in a sample are also abundant, the equity index must take the maximum value, and decreases, tending to zero, as the relative abundances of species diverge from its equality. It has as parameters Simpson and Shannon indices. The Hill index can cause some misunderstandings in some particular cases: reaches high value when equity is high or when a species dominate the community [15].

Alatalo index is known as Hill modified index. This index will approaching zero as the smaller gender equality in the composition of species in different plots [16]. This index is not recommended because, when used in comparisons, tends to overvalue the equity, having a non-linear relationship with this [15].

\subsubsection{Beta diversity}

Beta diversity or among habitats represents the degree of change of species, as well as biotic change through environmental gradients [6]. It is based in proportions or differences, that can be quantified based on indices or similarity coefficients of dissimilarity or distance between the plots, from quantitative or qualitative data, as well as by beta diversity indices themselves.

The easiest system to measure beta diversity between pairs of localities is through the use of similarity coefficients [5]. The most used is the Jaccard and Sorensen indices (Table 1). These indices are designed to be equal to 1 if there are complete similarity cases (when the two species are identical) and equal to zero if the plots are dissimilar and have no species in common. One of the great advantages on these measures is your simplicity. However, this can also be a disadvantage, since the coefficients do not consider the abundance of species. All species have an equal weight in the equation, whether abundant or rare [5].

\section{Results and discussion}

\subsection{Natural regeneration}

The diversity indices calculated at work (Table 2) included the contents of Margalef and Menhinick (species richness); Simpson and MacIntosh (dominance); Shannon (information); Pielou, Alatalo and Hill (equity) and Jaccard and Sorensen (similarity).

The value found by index of Margalef (3.81) featuring low diversity when compared to other regeneration areas. In a study of similarity in floristic composition between an area of natural regeneration of Mixed Rainy Forest and natural regeneration in an adult Brazilian pine plantation, in Irati, Paraná [21], the authors found a value of 10.68 floristic diversity in Margalef index for the Mixed Rainy Forest, denoting high floristic diversity. The low diversity in the present study may be explained by the fact that the index does not consider the size of the sampled area, which in this case is less than the commonly found in the works. 


\begin{tabular}{llll}
\hline Diversity indices & Values & Classification $^{*}$ \\
\hline Species richness & Margalef index & 3.81 & Low diversity \\
Menhinick index & 2.05 & High diversity \\
Dominance & Simpson index & 0.21 & Low dominance \\
& MacIntosh index & 0.64 & Low dominance \\
Information & Shannon index & 2.13 & Medium diversity \\
Equity & Pielou index & 0.76 & High uniformity \\
& Alatalo index & 0.65 & High uniformity \\
Similarity & Hill index & 0.71 & High uniformity \\
& Jaccard index & 0.24 & Low similarity \\
& Sorensen index & 0.38 & Low similarity \\
\hline
\end{tabular}

*Sorting by comparing values found in similar areas in other works.

Table 2. Alpha and Beta diversity indices for the natural regeneration.

The Menhinick index denoted high diversity through the value of 2.05. Even without taking into consideration the size of the sampling area, different of Margalef index, represents, in this case, the diversity of real way in the area, even a small sampling area.

The indices of dominance express if there is dominance by one or a few species in the sampled area. In species dominance, the two indices, Simpson and MacIntosh, presented low dominance by one or a few species on the plots with values of 0.21 and 0.64 , respectively.

The most commonly used indices are those based on information theory. These indexes express directly the value of diversity at that location; the most used is the Shannon index. For this index, we found an average of 2.13, which is characteristic of species diversity for the average site. Similar values were found using the same size of sampling units in the FLONA of São Francisco de Paula [18], with a value by the Shannon index of 2.22. Due to the high density of individuals that occur in natural regeneration, and these are heavily clustered, the Shannon index have a good representation of the diversity of natural regeneration even in smaller sampling units.

The equity indexes show how the number of individuals are distributed among the species, denoting less or greater uniformity in the composition of the parcels. For the area in question, the three indices used, Pielou, Alatalo, and Hill showed the same trend in each sub-plot evaluated by means of the average values of $0.76,0.65$, and 0.71 , respectively, which denotes high uniformity in composition of species on the plots.

On natural regeneration, the Jaccard index varied from 0 to parcels with less interaction, up 0.75 to parcels with greater interaction, with an average of 0.24 , which denotes low floristic similarity between the plots. Already the Sorensen index reached values from zero to the natural regeneration in smaller plots, interaction to 0.86 to portions of greater interaction, with an average of 0.38 , featuring low floristic similarity. In the FLONA of São Francisco 
de Paula, in portions of $100 \times 100 \mathrm{~m}$ [11], the authors found high similarity between floristic groups formed within the area through Sorensen index, with values ranging from 0.66 to 0.75 .

\subsection{Arboreal component}

The studied indices for the arboreal component (Table 3) included the contents of Margalef and Menhinick (species richness); Simpson and MacIntosh (dominance); Shannon (information); Pielou, Alatalo and Hill (equity) and Jaccard and Sorensen (Similarity).

The value found for Margalef index denoted low diversity when compared to other areas of Mixed Rainy Forest. This low diversity can be explained by the fact that the index does not consider the size of sampled area, which in this case is less than the commonly found in other researches. In a study on FLONA of São Francisco de Paula [22], the authors found values for Margalef index, through 10 parcels of $100 \times 100 \mathrm{~m}$, which ranged from 6.24 to the lower portion to 10.05 for greater diversity, with an average of 8.38 , denoting high diversity in the arboreal component. It allows us to conclude that this index is not ideal for assessing the diversity in small areas, such as those used in this work $(10 \times 10 \mathrm{~m})$.

In a research of floristic and structural changes that have occurred in a Mixed Rainy Forest, located in São João do Triunfo, PR [23], the authors found a value in the year 1979, of 6.52 and in the year 2000, of 7.02 for Margalef index, featuring of medium to high biodiversity.

The Menhinick index presented a 1.96 value of species richness. This value represented medium to high diversity in the study area, when compared to other areas of the same type. Also in the FLONA of São Francisco de Paula [22], however, with plots of $100 \times 100 \mathrm{~m}$, the authors found an average of 1.96 for Menhinick index, denoting high species richness.

\begin{tabular}{llll}
\hline Diversity indices & & Values & Classification $^{*}$ \\
\hline Species richness & Margalef index & 2.20 & Low diversity \\
& Menhinick index & 1.96 & $\begin{array}{l}\text { Medium to high } \\
\text { diversity }\end{array}$ \\
Dominance & Simpson index & 0.26 & Low dominance \\
& MacIntosh index & 0.80 & Low dominance \\
Information & Shannon index & 1.54 & Low diversity \\
Equity & Pielou index & 0.93 & High uniformity \\
& Alatalo index & 0.88 & High uniformity \\
Similarity & Hill index & 0.91 & High uniformity \\
& Jaccard index & 0.12 & Low similarity \\
& Sorensen index & 0.21 & Low similarity \\
\hline
\end{tabular}

*Sorting by comparing values found in similar areas in other works.

Table 3. Alpha and Beta diversity indices for the arboreal component. 
In the same study of floristic and structural changes that have occurred in a Mixed Rainy Forest, located in Paraná [23], the authors found a value for Menhinick index of 1.10, in 1979, and 1.17 in 2000, characterized by medium diversity.

Even without considering the size of the sampling area, the Menhinick index, different of Margalef index, represents, in this case, the real diversity of the area, even a small sampling area. The suggestion would be in smaller sampling units, use the Menhinick index, and, in larger sampling units, Margalef index, both to assess the species richness within the area.

The dominance of species by the two indices, Simpson and MacIntosh, presented values of 0.26 and 0.8 , respectively. The contents of Simpson and MacIntosh presented low dominance by one or a few species on the plots. Other research found very similar values in Mixed Rainy Forest area in São João do Triunfo, PR [23], with 0.21, in the year of 1979, and 0.26 in 2000, for the Simpson index, and 0.97 (1979) and 0.96 (2000), for the MacIntosh index, characterizing low dominance by one or a few species in the area.

It is common to find misinterpretation in Simpson index, in which the authors use this index as a parameter of the diversity of local information, when in fact he expressed only the dominance of some species in the plot. Other researchers found values of 0.15 [24] and 0.04 [25] for the Simpson index in areas of Mixed Rainy Forest and interpreted as areas of middle and low diversity, when in fact these values indicate only that there are low dominance of one or a few species in the area, it means that there are, approximately, the same number of species in each sample unit.

We obtained a value for Shannon index of 1.54, denoting low diversity when compared to other studies. The low floristic diversity is common in Mixed Rainy Forest remnants located in areas of higher altitude, where the climatic rigors selective pressure on plant diversity [26].

These low values of diversity can also be a result of sample unit size, as well as the index of species richness of Margalef. In the same FLONA of São Francisco de Paula, in sampling units of $100 \times 100 \mathrm{~m}$ [22], the authors found values for the arboreal component between 2.78 to plots of less diversity, to 3.40 to the greater diversity, with an average of 3.19, which features high diversity. Also in the FLONA of São Francisco de Paula, others researches found high diversity in the areas sampled by the Shannon index, with values of 3.53 [27] and 2.95 [28]. Highest values of diversity were found in several works with Mixed Rainy Forest [17, 25, 29-32], which characterized the diversity in these areas of medium to high, according to the Shannon index.

Pielou, Alatalo, and Hill indices presented values of 0.93, 0.88, and 0.91, respectively, demonstrating high uniformity in the composition of the parcels. Other research [28], in the FLONA of São Francisco de Paula, also found high uniformity in the composition of the parcels, with value of 0.80 for the Pielou index. Similar values were also found in other areas of Mixed Rainy Forest, like [17] (Pielou $=0.90)$ and [32] (Pielou = 0.83).

Other research also found similar results by evaluating the arboreal component in National Forest of São Francisco de Paula, in sampling units of $100 \times 100 \mathrm{~m}$, with a value of 0.60 at Alatalo index and 0.63 for Hill index, featuring high uniformity. 
For the arboreal component, the Jaccard similarity index values varied between zero, for parcels with no interaction, which means that no species coincides in the composition of the two parcels, up to 1.00 for portions of greater interaction, meaning that all species present in a portion are equal to those in another. The average Jaccard index in arboreal component was 0.12, what characterizes low similarity in species composition between different plots. In $20 \times$ $100 \mathrm{~m}$ plot in a remnant of Mixed Rainy Forest in Santa Catarina [31], the authors also found low floristic similarity in composition of plots according to the Jaccard index, with values rarely exceeding 0.5 .

The coefficient of similarity of Sorensen reached values between 0 , to the parcels with less interaction, to 1 for parcels with greater interaction, with an average value of 0.21 , which denotes, as well as the Jaccard index, low similarity in species composition for different plots. These low values of similarity found for the two indices can be related to the size of the sampling unit.

\section{Conclusions}

The specific richness of Margalef index was highly influenced by the size of the sampling unit, obtaining values of diversity, both in arboreal component and in natural regeneration. As a result, this index is not suitable for assessing the diversity of Mixed Rainy Forest in small sampling units, as adopted in this methodology.

Even without considering the size of the sampling area, Menhinick index represented the diversity in a real way of the area, fact that indicates this index for diversity evaluation in small sampling units of Mixed Rainy Forest.

The Simpson and MacIntosh indices showed similar patterns, both to the arboreal component and natural regeneration, denoting low dominance of one or a few species. These values are similar to those found in other studies in Mixed Rainy Forest, which denotes that the two indices show the real dominance of species in these areas, in accordance with the methodology adopted.

The Shannon-Wiener index, which reports directly to the value of diversity at the site, showed an average value of 1.54 for the arboreal component, which denotes low diversity in place. This low value of diversity can also be a result of sample unit size, as well as the Margalef index.

On natural regeneration, the Shannon index was not influenced by the size of the sampling unit, showing an average of 2.13 , which denotes medium diversity in place.

The three equity indices used, Pielou, Alatalo, and Hill, showed the same pattern in each subplot evaluated, denoting high uniformity in the composition of the parcels. The indices presented the uniformity in composition of species on the plots, being suitable for the assessment of equity in Mixed Rainy Forest areas, according to the adopted methodology.

Beta diversity indices presented low similarity in the floristic composition of different samples with the low value may also be a consequence of the small area of sampled units. 


\section{Acknowledgements}

To FLONA of São Francisco de Paula, CAPES, and CNPQ.

\section{Author details}

Maria Raquel Kanieski ${ }^{1 *}$, Solon Jonas Longhi ${ }^{2}$ and Philipe Ricardo Casemiro Soares ${ }^{1}$

*Address all correspondence to: raquel.kanieski@udesc.br

1 Santa Catarina University State, Lages, Santa Catarina, Brazil

2 Santa Maria Federal University, Santa Maria, Rio Grande do Sul, Brazil

\section{References}

[1] Salas GR, Fidalgo B, Torres R. Relationship between biodiversity and structure indices in maritime pine forests: Usefulness in forest management. In: IUFRO, editor. Conference of the Biodiversity and Conservation Biology in Plantation Forests 2005; April, 2005; Bordeaux, France; 2005

[2] Dias BFS, Coradin L. Diversidade biológica e sua importância para o Brasil: Programa de Dados para a Conservação da Biodiversidade. PROBIO/SP: São Paulo, SP; 1999

[3] Ricklefs RE. Ecology. 3rd ed. New York, NY: Freeman; 1990. p. 456

[4] Noss RF. Assessing and monitoring forest biodiversity: A suggested framework and indicators. Forest Ecology and Management. 1999;115

[5] Magurran AE. Ecological Diversity and its Measurements. New Jersey, NJ: Princeton University Press; 1988. p. 179

[6] Whittaker RH. Evolution and measurement of species diversity. Taxon; 1972;21(2/3): 213-251

[7] Couto HTZ. Métodos de inventário da biodiversidade de espécies arbóreas. ESALQ/ FAPESP: Piracicaba, SP; 2005. p. 108

[8] Brasil. Lei 9.985/2000 [Internet]. 2000 [Updated: September 10, 2017]. Available from: http://www.planalto.gov.br/ccivil_03/leis/L9985.htm [Accessed: September 16, 2017]

[9] Alvares CA, Stape JL, Sentelhas PC, Gonçalves LM, Sparovek G. Köppen's climate classification map for Brazil. Meteorologische Zeitschrift. 2013;22(6)

[10] Embrapa. Sistema brasileiro de classificação de solos. Rio de Janeiro, RJ: EMBRAPA Solos; 1999. p. 412 
[11] Ribeiro SB, Longhi SJ, Brena DA, Nascimento AT. Diversidade e classificação da comunidade arbórea da Floresta Ombrófila Mista da Flona de São Francisco de Paula RS. Ciência Florestal. 2007;17(2)

[12] Narvaes IS. Classificação e caracterização da regeneração natural em Floresta Ombrófila Mista na Floresta Nacional de São Francisco de Paula, RS [dissertation]. Santa Maria, RS; 2004. p. 143

[13] Angiosperm Phylogeny Group. An update of the Angiosperm Phylogeny Group classification for the orders and families of flowering plants: APG II. Botanical Journal of the Linnean Society. 2003;141:399-436

[14] Waite S. Statistical Ecology in Practise: A Guide to Analysing Environmental and Ecological Field Data. Prentice Hall: London, EN; 2000. p. 414

[15] Moreno CE. Métodos para medir la biodiversidad. 1st ed. M \& T Manuales y Tesis SEA: Zaragoza; 2001. p. 84

[16] Ludwig JA, Reynolds JF. Statistical Ecology: A Primer on Methods and Computing. New York, NY: John Wiley \& Sons; 1988. p. 338

[17] Cordeiro J, Rodrigues WA. Caracterização fitossociológica de um remanescente de Floresta Ombrófila Mista em Guarapuava, PR. Árvore. 2007;31(3):545-554

[18] Narvaes IS, Brena DA, Longhi SJ. Estrutura da regeneração natural em Floresta Ombrófila na Floresta Nacional de São Francisco de Paula, RS. Ciência Florestal. 2005;15(4):331-342

[19] Pielou EC. Ecological diversity. New York, NY: John Wiley; 1975. p. 165

[20] Felfili JM, Rezende RP. Conceitos e métodos em fitossociologia. Brasília, DF: UNB; 2003. p. 68

[21] Saueressig D, Moraes CM, Walk F, Inoue MT, Figueiredo Filho A. Estudo da similaridade na composição florística entre uma área de Floresta Ombrófila Mista e a regeneração natural em um plantio adulto de pinheiro-brasileiro na FLONA de Irati. In: 14 Encontro Anual de Iniciação Científica; Guarapuava, PR: UNICENTRO; 2005

[22] Kanieski MR, Longhi SJ, Araujo ACB. Quantificação da biodiversidade em floresta ombrófila mista por meio de diferentes índices alfa. Scientia Forestalis. 2010;38(88):567-577

[23] Schaaf LB, Figueiredo Filho A, Franklin G, Sanquetta CR, Longhi SJ. Modificações florístico-estruturais de um remanescente de floresta ombrófila mista montana no período entre 1979 e 2000. Ciência Florestal. 2006;16(3):271-291

[24] Sousa SGA, Carvalho J, Barddal ML. Diversidade e estrutura fitossociológica de uma floresta ciliar do rio Iraizinho, Piraquara, PR. In: UFLA, editor. Ve Simpósio Nacional sobre Recuperação de Áreas Degradadas; Lavras, MG; 2008 
[25] Watzlawick LF, Sanquetta CR, Valério AF, Silvestre R, Caracterização d. composição florística e estrutura de uma Floresta Ombrófila Mista no município de General Carneiro (PR). Ambiência. 2005;1(2):229-237

[26] Roderjan CV, Franklin G, Saito YK, Santos EP. Caracterisation des unites phytogeographiques dans l.etat du Paraná Brasil et leur etat de conservation. Biogeographica. 2001;77(4):129-140

[27] Gomes JF, Longhi SJ, Araujo MM, Brena DA. Classificação e crescimento de unidades de vegetação em Floresta Ombrófila Mista, São Francisco de Paula, RS. Ciência Florestal. 2008;18(1):93-107

[28] Sonego RC, Backes A, Souza AF. Descrição da estrutura de uma Floresta Ombrófila Mista RS Brasil utilizando estimadores não-paramétricos de riqueza e rarefação de amostras. Acta Botânica Brasílica. 2007;21(4):943-955

[29] Nascimento AT, Longhi SJ, Brena DA. Estrutura e padrões de distribuição espacial de espécies arbóreas em uma amostra de Floresta Ombrófila Mista em Nova Prata RS. Ciência Florestal. 2001;11(1):105-119

[30] Seger CD, et al. Levantamento florístico e análise fitossociológica de um remanescente de Floresta Ombrófila Mista localizado no município de Pinhais Paraná-Brasil. Floresta. 2005;35(2):291-302

[31] Lingner DV, Oliveira YMM, Rosot NC, Dlugosz FL. Caracterização da estrutura e dinâmica de um remanescente de floresta com araucária no planalto catarinense. Pesquisa Florestal Brasileira. 2007;55:55-56

[32] Reginato M, Goldenberg R. Análise florística estrutural e fitogeográfica da vegetação em região de transição entre as Florestas Ombrófilas Mista e Densa Montana Piraquara, Paraná, Brasil. Hoehnea. 2007;34(3):349-364 